\title{
Coetzee's Postmodern Bodies: Disgrace between Human and Animal Bodies
}

\author{
Shadi S. Neimneh \\ English Department, Hashemite University, Zarqa, Jordan
}

\begin{abstract}
This paper looks at the intersection between human and animal bodies in J. M. Coetzee's postapartheid novel Disgrace (1999). My argument is that Coetzee employs postmodern notions about the overlap between human and non-human bodies and their proximity in his fiction. Although Coetzee problematizes our conception of the body in most of his other works, it is in Disgrace that we have a unique combination of human and animal bodies and a juxtaposition of each body against the other. Coetzee, I contend, writes within the rubrics of postmodern posthumanism whereby his works interrogate questions of life, death, embodiment, otherness, and the body. While it is characteristic of postmodernism to break down distinctions and to argue the irrelevance of borders, Coetzee applies this logic to his treatment of humans and animals and toward significant ethical and political ends. Through multiple encounters with animals, David Lurie in Disgrace is forced to reexamine the boundaries between animal and human life and, thus, to react differently to suffering and other forms of life around him.
\end{abstract}

Index Terms - Coetzee, South African fiction, body theory, Disgrace, post-apartheid literature, postmodernism

\section{INTRODUCTION: THE POSTMODERN BODY}

Postmodernism has a prominent cultural and ethical orientation inadequately explored in the field of literary studies. Its critique of essentialism, capitalism, and totality is commonplace. And its celebration of fragmentation, irony, and self-reflexivity is also well-known. However, postmodernism's emphasis on the body as an avenue for ethicopolitics is the subject of this article. My concern, though, is not the interest of postmodern culture with organ transplants, cosmetic surgery, "body-sculpting", or the body as a machine. Critics like Susan Bordo (1998) have described "this paradigm of plasticity" and exposed "the material and social realities that it denies or renders invisible" (p. 1100). Nor is my goal to establish the body as a foundational metanarrative in Coetzee's work because Coetzee displaces certainty with regard to the human body even when his work seems to invite a consideration of the body as a dominant discourse. In an interview with David Attwell (1992), Coetzee argues that the body has been a common thread in his fiction. He argues that the body in pain is beyond doubt: "Whatever else, the body is not 'that which is not,' and the proof that it $i s$ is the pain it feels...." (p. 248). He asserts being overwhelmed by suffering in the world and justifies his fiction by adding the following statement: "These fictional constructions of mine are paltry, ludicrous defenses against that being overwhelmed, and, to me, transparently so" (p. 248). Although Coetzee's argument seems to establish the body as the main narrative within his work, the linkage between the body, death, and suffering and the human/animal encounters we find in Disgrace (1999) make the novel a unique one among Coetzee's body narratives.

Instead of making the body in Coetzee's work a foundationalism or a grandnarrative, I try to examine the peculiarity of the body in Disgrace. I draw on other works by Coetzee and Franz Kafka when relevant for the postmodern orientation of this article and for purposes of contextualization. Moreover, I seek to establish the presence of the body in Coetzee's Disgrace to highlight the ethicopolitical orientation of his work. The alliance between postmodernism, on the one hand, and ethics and politics, on the other, comes as no surprise and is justified by the inclusive nature of postmodern logic. For one critic, "Postmodernism is no more idiosyncratic or singular than the world is general or normal" (Radhakirshnan, 2003, p. 1). Andrew Bennett and Nicholas Royle (2009) argue that in the postmodern nothing is absolute or certain: "all absolute values ... become sites of questioning, of rethinking, of new kinds of affirmation" ( $p$. 280). Therefore, postmodernism celebrates "the undecidable" (p. 280), which makes it a fit theoretical frame for a consideration of the interplay between human and animal bodies. However, Disgrace does not sacrifice an ethicopolitical dimension in its apparently cultural focus on the body. In The Politics of Postmodernism, Linda Hutcheon (2002) emphasizes the contradictory nature of postmodernism and finds the political potential of postmodernism against claims of "narcissistic and ironic appropriation" by showing how it works by turning its "inevitable ideological grounding into a site of de-naturalizing critique," thus problematizing representation (p. 3). Hutcheon asserts as her focus the politics of postmodern representation, "the ideological values and interests that inform any representation" (p. 7). Her model is a "paradoxical postmodernism of complicity and critique, of reflexivity and historicity" (p. 11). Following this logic, the novel's presentation of the body can be grounds for its political, social, historical, and ethical critique of South African realities.

Because postmodernism is critical of strict boundaries, my argument about the proximity and fluidity of human/animal bodies is relevant. Apparently, a contextualization of Disgrace within Coetzee's fiction in term of its 
treatment of animals is beyond the limited scope of this article, and so is a discussion of the Kafkan echoes insofar as the boundaries between the human and the animal are concerned. Therefore, I will be highly selective in my treatment of the novel's allusions to Kafka's works and its erasure of a strict line of demarcation between the animal and the human. I will also discuss briefly strong relevant echoes between this novel and Coetzee's other novels.

In Kafka's story "A Report for an Academy" (1917), an ape gives a speech to a learned audience. Red Peter is a talking ape speaking about his previous existence as an ape years ago. He now wavers between the body of an ape and the consciousness and most manners of a human being. "My ape nature," says the ape, "rushed head-over-heels out of me and away, so that my first instructor himself became almost ape-like as a result and had before long to abandon my instruction and be admitted to a mental hospital" (p. 227). Kafka's story is relevant because it captures the fluid postmodern divide between the animal and the human. In this story, the animal becoming human is just another version of the human becoming animal. Red Peter acquires a human consciousness and develops rhetorical skills while his instructor loses his ability to reason. However, the ape is constantly conscious of his embodied existence, of being trapped in the body of an animal, which justifies the itchy heel in my second epigraph from the story. In Disgrace, what we have are not literal or symbolic transformations of the sort we find in Kafka's "A Report for an Academy" or "The Metamorphosis" (1915) (where a man wakes up one morning to find himself transformed into a gigantic insect) but more of encounters between the human and the animal, and thus imaginative crossings of borders. Such encounters I am interested in are of the sort Jacques Derrida (2002) presents in “The Animal That Therefore I Am" where one's sense of identity is put to question and is subject to confusion upon an encounter face to face with the animal other, a cat in Derrida's account gazing back at him (p. 372). More references can be made to Coetzee's Michael K in Life and Times of Michael $K$ (1983) who is reduced to the status of an animal, living like a mole in an underground burrow and eating insects, in South Africa during the apartheid regime. In this novel, the becoming animal is figurative, a representation of life conditions in times of political unrest. And so is the case in Disgrace whereby animals signify the disgrace of ageing and suffering in the post-apartheid South Africa.

In The Lives of Animals (1999), Elizabeth Costello takes us further into questioning the boundaries between humans and animals. She offers the following argument: "To be alive is to be a living soul. An animal... is an embodied soul" (p. 33). She counters thinking and reasoning with being, sensation, or embodiedness (33): To thinking, "cogitation," she opposes "fullness, embodiedness, the sensation of being..." (p. 33). For Costello, "To be a living bat is to be full of being" (p. 33). In fact, she makes an argument for a limitless "sympathetic imagination" (p. 35) whereby there are "no limits to the extent to which we can think ourselves into the being of another" (p. 35). She offers a bodily way of relating to animals, a form of physical identification achieved mentally, though. Discussing the theme of embodiment in Elizabeth Costello, Elizabeth Susan Anker (2011) argues that "Costello's recognition of a shared human-animal predicament of corporeal woundedness provides an alternate basis for obligation both to animals and to other human beings, offering a competing philosophical ground for theorizing ethics and social justice" (p. 170). Costello takes the body as the starting point for a common life between humans and animals. The body becomes the site of ethical identification between humans and animals and among fellow human beings. Her argument that we can think ourselves into the being of animals is the opposite of what Kafka's ape does when he thinks himself into the being of humans and thinks and acts like them. In Kafka's 1922 story "Investigations of a Dog," a dog ruminates about its life, the nature of its food, and its bodily needs. In all of these works, the boundary between the human and the nonhuman is crossed and for a purpose that should be elaborated, be it political, ethical, or otherwise. This intersection between humans and animals can take the form of privileging the body over the mind, assuming the consciousness of human beings, and the figurative dehumanization associated with corrupt politics or simply getting old (and thus becoming a body). In the next section, I examine the problematic of the body in Disgrace and then highlight the human/animal encounters the novel depicts.

\section{The Problematic OF THE Desiring Body}

In Disgrace, Coetzee establishes the problematic of sexual desire that blights David Lurie at the very beginning of the novel. The body is presented as the protagonist's main problem. The novel's first sentence reads: "For a man of his age, fifty-two, divorced, he has, to his mind, solved the problem of sex rather well” (p. 1). Lurie's frustrations in marriage and professional life ${ }^{1}$ make him indulge in numerous sexual affairs with streetwalkers, a part-time prostitute called Soraya, a departmental secretary, and finally a student in one of his classes called Melanie Isaacs. The disgrace of this last affair in particular directly affects his life as he loses his job after being found guilty before the university committee that questions him. In a sense, Lurie has a problem coming to terms with the instinctive needs and desires of his body (as cited in Neimneh, 2013). Recollections of his affair with Melanie continue to stir his sexual desire throughout the novel. Married twice but divorced twice, he could not actually solve the problem of sex. And Lurie is not the only character in Coetzee's fiction who has a problem with the body in the form of trying to resolve sexual desire and the contingent shame associated with this desire.

For example, the Magistrate in Coetzee's Waiting for the Barbarians (1980) faces the problematic of sexual desire. His sex life seems odd; he frequents prostitutes and finds in the body of a barbarian girl an irresistible source of fascination and repulsion. He fetishizes her tortured feet, and his ritual of cleansing and rubbing often ends in fits of unsustainable erotic desire. The Magistrate finally makes love to her on their way to return her to her people. Back in 
his outpost, he continues to have this troubled relationship with his sexual desires, often experiencing his member as an alien, uncontrollable organ. In fact, his very relationship with the barbarian girl might have brought his downfall and subsequent "disgrace." People in the frontier gossip about his affair with this barbarian girl, and news reach the capital. His taking her to her people is seen as a violation, an act of consorting with the barbarian enemy. Therefore, the Magistrate is tortured and humiliated publicly by the Empire's officials. He is "disgraced" in the eyes of his people; his "disgrace" culminates when he is forced to wear a woman's smock for a mock crucifixion (as cited in Neimneh, 2013). The Magistrate loses all his privileges as an administrator in his outpost settlement and symbolically leads a dog's life. He is not allowed to wash himself; he wears dirty clothes; his food is rationed; he is mocked by children and imprisoned in a cell; he is pained and trots like a dog. Excessive torture makes him think: "There is no way of dying allowed to me, it seems, except like a dog in a corner" (p. 115). The dehumanized life he leads now also makes him think of himself as "a tired old bear" and "a filthy creature who for a week licked his food off the flagstones like a dog ..." (p. 113, p. 122). The Magistrate comes to experience his whole life in terms of bodily pain or self-preservative instincts like hunger and thirst. He is not symbolically different from the animals he compares himself to. The tripartite relationship between the desiring body, disgrace, and metaphorical animals is a common theme linking both novels. The animal (dogs in particular) becomes a trope for humiliation, for the base part of our existence we associate with the body. The body is a source of disgrace, and this disgraced body is often described in terms of animal imagery in Coetzee's fiction.

In the case of Disgrace, critics have observed the novel's treatment of the body as a theme. According to Sue Kossew (2003), the novel is "a complex exploration of the collision between private and public worlds; intellect and body; desire and love; and public disgrace or shame and the idea of individual grace or salvation" (p. 155). Kossew adds that Disgrace is a novel "in which bodies are very strongly linked to power, desire, and disgrace" (p. 156). Critics have not failed to mark the body as the novel's central problematic. For example, Gareth Cornwell (2002) notes that Coetzee in Disgrace "evokes the pathos of an aging man's recognition of the uselessness of his desire, the disgrace of its refusing to die" (p. 315). The ageing body becomes a source of disgrace because physical deterioration is inherent in the experience of embodiment. What critics have ignored, however, is Coetzee's postmodern conception of the body and the human/animal encounters in the novel as an inherent part of such a postmodern conception.

In Disgrace, the "honey-brown body" (p. 1) of a prostitute is the site of carnal love, a commodity possessed by the agency she works for. This commodification of the body makes love a mechanical relation and an escape from the nagging of desire. Lurie is a follower of Eros and a man leading a promiscuous life of affairs. "He has always been a man of the city, at home amid a flux of bodies where eros stalks and glances flash like arrows" (p. 6). At the same time, he "had affairs with the wives of colleagues; he picked up tourists in bars on the waterfront or at the Club Italia; he slept with whores" (p. 7). A failed sexual fling with his department's secretary makes him think in the following terms: "He ought to give up, retire from the game. At what age, he wonders, did Origen castrate himself?" (p. 9). The disgrace of ageing and dying make him think of castrating himself: "A man on a chair snipping away at himself: an ugly sight, but no more ugly, from a certain point of view, than the same man exercising himself on the body of a woman" (p. 9). But Lurie is in the grip of eros when he pursues Melanie. When he calls her home for the first time to invite her out, he is "in the grip of something" (p. 18). A sexual adventure with her is described in terms of forceful desire on his part and lack thereof on her part:"Not rape, not quite that, but undesired nevertheless, undesired to the core" (p. 25). Even in times not timely for sexual love he remembers her with lust as he sees her riding a motorcycle with knees apart (p. 35) or when she comes to him crying (p. 26).

Desire makes Lurie think of animal life. He links the human body to metaphorical animals. Lurie thinks of the intercourse between himself and Soraya in terms of "the copulation of snakes" (p. 3), a copulation that is "lengthy, absorbed, but rather abstract, rather dry, even at its hottest" (p. 3). If he were to choose a totem, he thinks, it would be the snake (p. 2). He exists "in an anxious flurry of promiscuity" (p. 7) trying to come to terms with the demands of his body. Ageing is a state of disgrace in that Lurie thinks of castrating himself. At least he thinks of castration, of the sort often done to animals: "they do it to animals every day, and animals survive well enough, if one ignores a certain residue of sadness" (p. 9). Ageing, castration, love/mating, and death are common to the lives of humans and animals. What precedes Lurie's encounter with animals - with the body of the other-are raw encounters with his own sexed body and the bodies of women he has sex with. A follower of Eros, Lurie has a heart that "lurches with desire" (p. 20). His love to his student is described in terms of animal imagery and as if she were "a rabbit when the jaws of the fox close on its neck" (p. 25). He deems himself to the university committee be "a servant of Eros" (p. 52). He pleads guilty but he refuses to issue a statement of public apology. He goes to the Eastern Cape to his daughter's smallholding. It is in this part of the story that the overlap between human and animal bodies begins. Lucy takes cats and dogs in her farm, which allows for the human/animal encounters I discuss in the next section.

Lurie tells Lucy a story about a male dog that the neighbours kept when Lucy was young and living in Kenilworth. The dog would get excited if a bitch got close. Its owners would beat it to the extent that it "had begun to hate its own nature" (p. 90). According to Lurie, "No animal will accept the justice of being punished for following its instinct" (p. 90). He tells this story to his daughter because he felt so sometimes. He admits, however, that "Sometimes I have felt just the opposite. That desire is a burden we could well do without" (p. 90). Lurie allegorizes animals to expose his corporeal predicament in a desiring body. The animal here becomes an objective correlative for the human, a trope for human desires. In other words, desire is the animal within. And following the same logic, he who succumbs to Eros 
metaphorically becomes an animal. Lurie uses animals to expose the human condition of embodiment. In other words, he draws on animals to reveal common aspects of existence.

\section{HUMAN/ANIMAL ENCOUNTERS}

In Disgrace, Coetzee presents an intricate account of the interrelationship between the animal and the human. The novel, roughly speaking, follows the deteriorating fortunes of its "sensual" protagonist, a divorced university professor in his fifties. Erotic desire seems to initiate the downfall of Lurie; after the sexual abuse of a student in his Romantics class at Cape Technical University, Lurie is forced by the university administration to resign his post. He leaves Cape Town to live with his daughter Lucy in a smallholding in Salem village in the Eastern Cape. There, he and his daughter are attacked by a gang of three black Africans. He is burned and beaten while his daughter is repeatedly raped, and thus made pregnant. By the end of the novel, Lurie is reduced to a dehumanized existence, working among dogs at a local veterinary clinic and acting as a caretaker for dead dogs by ferrying their corpses to the incinerator. In a sense, he becomes "the dog man."

Lurie sees his new life as that of a dog. Like his daughter Lucy, Lurie learns to accept humiliation and brutalization as part of the historical guilt of his ancestors. He and his daughter, as white South Africans, pay a price for a history of racism against and subjugation of black African people. Their personal history is stained with the colonial guilt of apartheid. They know now that they should lead a humiliating life like that of a dog. Negotiating Lucy's plan to give up her land to Petrus, a greedy African worker assisting her in this time of changed power relations, the following exchange takes place between Lurie and his daughter:

'How humiliating,' he says finally. 'Such high hopes, and to end like this.'

'Yes, I agree, it is humiliating. But perhaps that is a good point to start from again. Perhaps that is what I must learn to accept. To start a ground level. With nothing. Not with nothing but. With nothing. No cards, no weapons, no property, no rights, no dignity.'

'Like a dog.'

'Yes, like a dog.' (p. 205)

The ending of this dialogue is clearly reminiscent of references to dogs in Coetzee's Waiting for the Barbarians and Kafka's The Trial, and can be further explored in longer critiques. In Kafka's The Trial (1925), Joseph K. dies full of shame and guilt for failing to end his own life or discover the nature of his guilt. His last words to the warders who drive a knife into his chest describe his shameful death: "Like a dog!" It seems that K's and the Magistrate's "disgrace" is not that different from Lurie's disgrace, or the disgrace of his daughter for that matter. Lucy is pregnant now as a result of her gang-rape by strangers. She too is in a state of disgrace. Lurie's disgrace also becomes that of the rape of his daughter, that of reducing her to a mere body by three black men. The rapists own the story of objectifying her body: "How they put her in her place, how they showed her what a woman was for" (p. 115). For Lucy rape is akin to killing, like driving a "knife" in and "exiting afterwards, leaving the body behind covered in blood" (p. 158). It is similar to what Bev Shaw does when she drives the needle in animal bodies. In a sense, rape dehumanizes the victim. Moreover, it equally reduces the victimizer to the status of animals. Therefore, rapists are also viewed by Lucy as "dogs in a pack" (p. 159). Commenting on the rape scene of Lucy, the killing of the dogs, and the attempt to burn Lurie, Moore (2001) argues: "We see the violence done to the house, to the dogs, to the father" (p. 466). Just as humans and animals equally enact desire, they also partake in being the objects of violence.

Human desire is expressed in terms of animal bodies. Animals for Lucy and her father metaphorically represent human shame. Lucy has to accept the humiliation of being a wife for Petrus in return for protection, to accept having an illegitimate child. Lurie has to accept the humiliation of living among unwanted animals and having to leave the intellectual realm of university life. Similarly, he has to cope with an ageing body with "bowed shoulders and skinny shanks" (p. 150). Ageing is a source of disgrace just as desire is a source of shame. While dogs metaphorically stand for the dehumanization and humiliation associated with apartheid and its aftermath, dogs viscerally suffer at the hands of humans.

Bev Shaw is an animal lover running a local clinic for animals. Lurie's daughter Lucy is one of the animal welfare people. In a conversation with her father, Lucy thinks that "On the list of the nation's priorities, animals come nowhere" (p. 73). Lucy is suggesting that animals have been the objects of oppression in South Africa. Lurie is different. His initial attitude toward animals is one of indifference. He is an intellectual, a man of books and a follower, or even a servant, of "Eros" (p. 52, p. 89). For Lucy, intellectual pursuits do not necessarily lead to a higher life. At a pivotal point in the novel, and while driving to the house, she tells him: "This is the only life there is. Which we share with animals. That's the example that people like Bev try to set. That's the example I try to follow. To share some of our human privilege with the beasts. I do not want to come back in another existence as a dog or a pig and have to live as dogs or pigs live under us" (p. 74). For Lucy, humans and animals live on an equal footing. Lurie responds: "Yes, I agree, this is the only life there is. As for animals, by all means let us be kind to them. But let us not lose perspective. We are of a different order of creation from animals. Not higher, necessarily, just different. So if we are going to be kind, let it be out of simple generosity, not because we feel guilty or fear retribution" (p. 74). At this stage, Lurie argues for difference among species and different orders of being. His intellectual detachment from animal life precedes actual encounters with animals at a close distance. 
In her yard, Lucy keeps animals, which is how human/animal encounters for Lurie begin. He enters one cage one day and stretches and relaxes next to a dog "on the bare concrete" (p. 78), thus becoming one with animals in the sense of sharing their embodied mode of existence. The bitch is a deserted, unwanted one. Lucy argues in defence of animals that they "do us the honour of treating us like gods, and we respond by treating them like things" (p. 78). He argues that the souls of animals are "tied to their bodies and hence die with them" once they die (p. 78). When some black men attack him and his daughter, one attacker shoots the dogs in the cages (p. 95). One German Shepherd is shot: "There is a heavy report; blood and brains splatter the cage" (p. 95). The dogs are reduced to a body mass. Chris Danta (2007) argues that it is the "disgrace of dying" that "truly merges human and animal suffering" (p. 734). Lurie witnesses animal and human suffering first-hand. He lives their disgrace just as he lives his own. He is humbled by his physical proximity to animal lives and suffering.

Lurie buries the six dogs killed by the three invaders by tumbling them into a hole. This is his second real encounter with animal bodies. One dog with a "hole in its throat still bares its bloody teeth" (p. 110). Lurie observes the aftermath of violence on his own body that gets burned and mauled, that of his daughter, and the corpses of dogs. Another human/animal encounter is that of the two sheep Petrus keeps for a party tethered next to a stable. Lurie thinks they should be tied, he tells Petrus, "where they can graze" (p. 123). He thinks that "Sheep do not own themselves, do not own their lives" (p. 123) because humans use them. For Lurie, Petrus should not bring the animals to where the people who will eat them can see them (p. 124). In fact, he relocates them to where they can graze near the dam "where there is abundant grass" (p. 123). When the next day he finds them back in the barren area near the stable, he thinks of such country ways in terms of "indifference, hardheartedness" (p. 125). In a sense, animals bring about an ethical awakening in Lurie. He begins to identify with animals by seeing them as his existential peers and bodily equals.

Just like the Magistrate in Waiting for the Barbarians who waits for a sign in the ruins outside his imperial post, Lurie examines the sheep: "He stands before them, under the sun, waiting for the buzz in his mind to settle, waiting for a sign" (p. 126; my emphasis). It is because "A bond seems to have come into existence between himself and the two Persians, he does not know how. The bond is not one of affection. It is not even a bond with these two in particular, whom he could not pick out from a mob in a field. Nevertheless, suddenly and without reason, their lot has become important to him" (p. 126). The idea here is a new form of communion with animals, the threshold of such a communion between Lurie and animals on the basis of physical proximity and face-to-face encounters. Bev Shaw seems to have accomplished such communion. He is still undergoing a change, though not without some resistance. Previously, he argued that animals do not have proper souls or lives since their souls are attached to their bodies. Now he admits to Lucy that in the case of the sheep he did not change his ideas but he is "disturbed" for reasons he cannot fathom (pp.126-7). He is exploring the limits of his sympathies with animals: "Should he mourn? Is it proper to mourn the death of beings who do not practise mourning among themselves? Looking into his heart, he can find only a vague sadness" (p. 127). This mysterious sadness is grounds for a form of sympathetic identification with animals, a mental crossing of boundaries between the human and the animal.

At the very end of Disgrace, Lurie gives up a dog he has developed an affinity with for a lethal injection (p. 220). Considering Lurie and his daughter's multifold disgrace in this novel, one can argue that this act is symbolic. If their disgrace is complete now, they have no future in this post-apartheid South Africa except that of the diseased or unwanted dogs which are disposed of. The end of the novel brings us back to the dogs. Lurie helps Bev on Sunday with a session of killing, "Lösung" (p. 218). Such an act delivered to maimed unwanted dogs is for him a form of "love" (p. 219). He takes one young and crippled dog out of the cage and the dog licks him: "Bearing him in his arms like a lamb, he re-enters the surgery. 'I thought you would save him for another week,' says Bev Shaw. 'Are you giving him up?' 'Yes, I am giving him up."” (p. 220). For Michalinos Zembylas (2009), such an act of giving up the dog is "symbolic of relinquishment of desire" and acceptance of "responsibility for the Other" (p. 225). It is as if Lurie gives up the desiring human body and embraces the sentience of being with animals. Formerly, he stood facing the sheep at a close distance. Now, Lurie carries the dog in his arms. The space between the animal and the human is crossed. Lurie becomes one with animals in the process of caring for unwanted dogs. The human body and the animal body overlap and intertwine.

I have suggested that Lurie is reduced to a body, working non-stop on the farm and at the clinic, doing all the chores like cooking, sweeping, shopping, and helping Bev with animals Shaw (p. 120). He assists in killing dogs at the Animal Welfare clinic, mainly unwanted dogs. But killing is a form of love and attention for such diseased animals: "To each, in what will be its last minutes, Bev gives her fullest attention, stroking it, talking to it, easing its passage" (p. 142). However, he does not get used to the idea of assisting in killing. He becomes "more jittery" (p. 142). One day he even stops at the roadside "to recover himself. Tears flow down his face that he cannot stop; his hands shake" (p. 143). This is a shift in his personality he does not understand. What he frequently does not seem to be hardening him towards animals. "His whole being is gripped by what happens in the theatre" of death (p. 143). He thinks that dogs sense that their end is approaching, that they feel "the disgrace of dying" (p. 143). They share his state after his sex scandal and the attack on his body and that of his daughter. They sniff him and lick his hands. On the other hand, Bev Shaw strokes them and touches them (p. 143). Humans and animals get in touch. Physical proximity reduces both to a bodily being. Lurie drives dead dogs immediately to a hospital incinerator. He personally oversees disposing of them so that they are not left with other forms of refuse or waste or wait unnecessarily: "He is not prepared to inflict such dishonour upon them" (p. 144). What he does is out of respect for dead bodies, for stiff bodies that underwent "rigor mortis" (p. 144). 
Dealing with ageing and dead animals is a form of initiation for Lurie whereby he comes to terms with the body in its different states - alive or dead.

Alice Brittan (2010) has called David "a spirit guide" and a "psychopomp" (p. 489) whose duty is "to continue to think of the dead after others have stopped, not to mourn them, but to enfold them in the imaginative grace that might allow the dead to recognize and understand their new and unfamiliar state, and the living to enlarge the precincts of what we can know" (p. 489). His task is therefore one of imaginative accommodation. Deirdre Coleman (2009) argues that Lurie in the course of the novel comes to recognize and accept "a shared emotional life with animals" (p. 599). Coleman writes that Lurie "sheds not only his anthropological outlook but his anthropocentric one as well" (p. 599) and moves between one version of Darwinism of struggle to another of continuity across species (p. 598). Coleman asserts that by the end of the novel Lurie, in a Darwinian fashion, comes to recognize "the evolutionary and emotional continuity between human and nonhuman species" (p. 613). This means that Lurie begins to appreciate the fluidity of bodily being in this life. It is not that human and animal bodies literally mutate into each other. Rather, Lurie comes to grasp embodiment as a common fate for humans as well as animals. Philip Rice and Patricia Waugh (1989) argue that postmodernists "see knowledge of the world as indissociable from being-in-the-world: knowledge and experience are inextricably bound to each other and always culturally situated" (p. 290). Lurie gets to enact this postmodern principle. He learns to unify the intellectual rigidness of his academic training with his sympathetic experience with diseased and dead animals.

For Harold Fromm (2000), Coetzee's Elizabeth Costello as an ecological thinker "wants to extend the range of personhood (in varying degrees) to include animals and is militantly opposed to a Cartesian cogito that favors rational consciousness over animal sentience" (p. 340). This applies to a transformed Lurie and animal lovers in Disgrace. An embodied being is the sentience we share with animals. Embodiment is Disgrace becomes more manifest after death and as Lurie deals with dog corpses. Lurie becomes a dog undertaker, a dog-man. He does not literally become a dog, but this is part of the novel's concern with the fluidity of existence. Death and killing become a form of love as well for Lurie just as disgrace becomes a form of grace. Disgrace and its opposite, dignity, seem to apply to both animals and humans in this novel. At one level, animality is an issue of animalization. It is a state humans are rendered to emotionally and psychologically via their actions. On the other hand, the body, be it human or animal and as an object of suffering, is viscerally material and real.

\section{CONCLUSION: FLUID BODIES AND ETHICOPOLITICS}

Mike Marais (2011) applies the rhetoric of sympathy to postcolonial fiction that racializes the body. For Marais, sympathy has an "ethical potential": "Through its proximity with the body, sympathy constantly intimates the possibility of responding to other bodies as singular entities, that is, in a non-conceptual way that does not reduce their otherness" (pp. 94-95). When sympathy becomes a form of identification with the body of the other, such mental identification transcends bodily boundaries between self and other. Bodily proximity is a crucial step toward an ethical attention to otherness. In Coetzee's fiction, an encounter with the body of the other is often an ethical encounter which can effect a change in perspective.

Coetzee's play with the proximity of humans and animals stems from the historical and political context of his novel. It is a history of violations and injustice whereby the denial of human rights reduced people to the figurative status of animals and counter violence reduced others to the same figurative status of disgraced animals. In a post-apartheid South Africa, the apathy of strained human relations and the mistreatment of animals are analogous. Victims and perpetrators of violence become alike in partaking in a dehumanized existence. Therefore, Coetzee frames his postmodern conception of fluid and close human/animal bodies within ethical and political considerations.

Louis Tremaine (2003) argues that Coetzee typically uses animals as "narrative elements associated with suffering and death" (p. 595). By contrast, Marianne DeKoven (2009) argues that in caring for dead dogs and identifying with them Lurie is actually enacting his own idea of "the proper relation to the death of 'body-souls full of being"" (p. 866). Lurie, it seems, comes to terms with the problematic of the body that began the novel through encountering animal suffering. He resolves the issue of desire and the body by learning to accept death and suffering as inherent to human life. He gets to take the materiality of the dying body for granted.

Don Randall (2007) writes that "Coetzee's writing registers and then counters this atrocious modernity by opening and extending the ethical bounds of human community, by envisioning animals as fellow beings deserving the consideration and protection that more typically are accorded only to the human being" (p. 209). Randall contends that Coetzee employs animals toward social, political, and ecological ends: "Intensified focus on the animal enables Coetzee to write in a zone of intersection between sociopolitical and ecological concerns, to elaborate an ecologically oriented ethics that sharpens the critique of modern political regimes that dominate and exploit fellow beings both human and non-human" (p. 210). Coetzee's ethicopolitical vision is as inclusive as postmodernism is. He uses the body to deliver a message about the corporeal predicament of humans and animals alike. It is the body that nags, desires, and gets violated. It is also the body that gets old/sick, suffers, and dies.

Postmodernism is not politically or ethically evasive. For a critic like Andrew Gibson (1999), twentieth-century postmodern novels are of "cardinal importance" to the "ethical critic" (p. 18). Employing the work of Emmanuel Levinas, Gibson speaks of "postmodern ethics" (p. 13) allowing for an ethical consideration of postmodern fiction. 
Coetzee depicts apathy and otherness permeating human life and governing our typical reaction to animal life. Coetzee is extending the ethical and political orientation of his fiction by juxtaposing humans against animals. In Disgrace, feeling into the existence of another body seems to have a disarming ethical force with the power to reform those who empathize and politically reform those who transgress. Had Lucy's rapists or Lurie himself identified with their sexual victims, the violations they perpetrated on the body of the other would not have taken place.

\section{NOTES}

David Lurie, married twice and divorced twice, is thus leading an empty emotional life. He was relegated from a professor of linguistics and literature at Cape University to an adjunct lecturer in communications in the same institution, now called Cape Technical University (p. 3). He is a man with a risky lifestyle.

\section{REFERENCES}

[1] Anker, E. S. (2011). Elizabeth Costello, embodiment, and the limits of rights. New Literary History 42, 169-192.

[2] Bennett, A. and N. Royle. (2009). An introduction to literature, criticism, and theory (4 ${ }^{\text {th }}$ edn.). Harlow: Pearson.

[3] Bordo, S. (1998). 'Material girl': The effacements of postmodern culture. In J. Rivkin and M. Ryan (eds.), Literary theory: An anthology. Malden: Blackwell, 1099-1115.

[4] Brittan, A. (2010). Death and J. M. Coetzee's Disgrace. Contemporary Literature 51.3, 477-502.

[5] Coetzee, J. M. (1999). Disgrace. New York: Viking.

[6] Coetzee, J. M. (2003). Elizabeth Costello. New York: Viking.

[7] Coetzee, J. M. (1992). Interview. Doubling the point: Essays and interviews. David Attwell (ed.). Cambridge, MA: Harvard U $\mathrm{P}, 243-250$.

[8] Coetzee, J. M. (1999). The lives of animals. Amy Gutmann (ed.). Princeton, NJ: Princeton UP.

[9] Coetzee, J. M. (1980). Waiting for the barbarians. New York: Penguin.

[10] Coleman, D. (2009). The 'dog-man': Race, sex, species, and lineage in Coetzee's Disgrace. Twentieth Century Literature 55.4, 597-617.

[11] Cornwell, G. (2002). Realism, rape, and J. M. Coetzee's Disgrace. Critique 43.4, 307-322.

[12] Danta, C. (2007). 'Like a dog ... like a lamb': Becoming sacrificial animal in Kafka and Coetzee. New Literary History 38, 721737.

[13] DeKoven, M. (2009). Going to the dogs in Disgrace. ELH 76.4, 847-875.

[14] Derrida, J. (2002). The animal that therefore I am (more to follow). David Wills (trans.). Critical Inquiry 28.2, 369-418.

[15] Fromm, H. (2000). Coetzee's postmodern animals. The Hudson Review 53.2, 336-344.

[16] Gibson, A. (1999). Postmodernity, ethics, and the novel: From Leavis to Levinas. London: Routledge.

[17] Hutcheon, L. (2002). The politics of postmodernism ( $2^{\text {nd }}$ edn.) London: Routledge.

[18] Kafka, F. Stories 1904-1924. (1995). J.A Underwood (trans.). A report for an academy. London: Abacus. 219-228.

[19] Kossew, S. (2003). The politics of shame and redemption in J. M. Coetzee's Disgrace. Research in African Literatures 34.2 , $155-162$.

[20] Marais, M. (2011). Violence, postcolonial fiction, and the limits of sympathy. Studies in the Novel 43.1, 94-114.

[21] Moore, J. R. (2001). Coetzee and the precarious lives of people and animals. The Sewanee Review 109.3, 462-474.

[22] Neimneh, S. (2013). J. M. Coetzee's Disgrace: eros, (dis)grace, and the body. International Journal of Applied Linguistics and English Literature 2.2, 172-178.

[23] Radhakrishnan, R. (2003). Theory in an uneven world. Malden, MA: Blackwell.

[24] Randall, D. (2007). The community of sentient beings: J. M. Coetzee's ecology in Disgrace and Elizabeth Costello. ESC 33.1-2, 209-225.

[25] Rice, P. and P. Waugh. (1989). Modern literary theory: A reader ( $3^{\text {rd }}$ edn.). London: Arnold.

[26] Tremaine, L. (2003). The embodied soul: Animal being in the work of J. M. Coetzee. Contemporary Literature 44.4, 587-612.

[27] Zembylas, M. (2009). Bearing witness to the ethics and politics of suffering: J. M. Coetzee's Disgrace, inconsolable mourning, and the task of educators. Studies in Philosophy and Education. 28, 223-237.

Shadi S. Neimneh is assistant professor of literary and cultural studies and Head of the English department at Hashemite University, Jordan. He earned a Ph.D. in literary studies from Oklahoma University (USA) in 2011. He has published numerous articles in international journals on the South African literature of J. M. Coetzee and diverse aspects of literary modernism. 